\title{
Odmienny wzorzec bioelektrycznej aktywności spoczynkowej mózgu u dzieci z dysleksją
}

\section{Altered pattern of resting bioelectrical activity in children diagnosed with dyslexia}

\author{
Monika Lewandowska ${ }^{1}$, Rafał Milner², Małgorzata Ganc², Elżbieta Włodarczyk ${ }^{3}$, \\ Agnieszka Pluta ${ }^{1}$, Henryk Skarżyński ${ }^{4}$ \\ ${ }^{1}$ Instytut Fizjologii i Patologii Słuchu, Światowe Centrum Słuchu, Naukowe Centrum Obrazowania \\ Biomedycznego, Kajetany \\ ${ }^{2}$ Instytut Fizjologii i Patologii Słuchu, Światowe Centrum Słuchu, Zakład Audiologii Eksperymentalnej, Kajetany \\ ${ }^{3}$ Instytut Fizjologii i Patologii Słuchu, Światowe Centrum Słuchu, Klinika Audiologii i Foniatrii, Kajetany \\ ${ }^{4}$ Instytut Fizjologii i Patologii Słuchu, Światowe Centrum Słuchu, Kajetany
}

Adres autora: Monika Lewandowska, Światowe Centrum Słuchu, Naukowe Centrum Obrazowania

Biomedycznego, ul. Mokra 17, Kajetany, 05-830 Nadarzyn, e-mail: m.lewandowska@ifps.org.pl

\section{Streszczenie}

Cel: Celem pracy jest określenie wzorców spoczynkowej bioelektrycznej aktywności mózgu u dzieci z dysleksją.

\begin{abstract}
Materiał i metody: W badaniach uczestniczyło 36 dzieci z rozpoznaną dysleksją oraz 27, dobranych pod względem płci i wieku, dzieci bez zaburzeń czytania (grupa kontrolna). Rejestrację sygnału EEG przeprowadzono w dwóch oddzielnych blokach relaksacji: z oczami otwartymi oraz z oczami zamkniętymi. Uzyskany sygnał EEG poddano analizie ilościowej (ang. quantitative EEG, qEEG). Przed przystąpieniem do badania EEG każda osoba badana wykonała testy czytania sensownych i sztucznych wyrazów.
\end{abstract}

\begin{abstract}
Wyniki: Wykazano specyficzny wzorzec spoczynkowej czynności elektrofizjologicznej mózgu u dzieci z dysleksją, przejawiający się wzmożoną ekspresją fal wolnych (delta, theta) oraz fal szybkich beta w zakresie 18-35 Hz, szczególnie w okolicach skroniowych. Ponadto tylko w grupie kontrolnej moc sygnału w paśmie fal wolnych ujemnie korelowała z szybkością czytania sensownych wyrazów, a u dzieci z dysleksją - im więcej poprawnie przeczytanych sztucznych wyrazów, tym większa była moc sygnału beta (18-35 Hz) w elektrodach skroniowych (T5 i T6).
\end{abstract}

Wnioski: Wyniki badań bioelektrycznej aktywności spoczynkowej mózgu u dzieci z dysleksją wskazują na związek fal delta, theta i beta $(18-35 \mathrm{~Hz})$ z procesem czytania. Badania mogą przyczynić się do rozwoju istniejących metod diagnostyki i terapii zaburzeń językowych.

Słowa kluczowe: dysleksja • aktywność spoczynkowa mózgu • ilościowa analiza EEG

Abstract

Aim of the study: The goal of this study was to identify the patterns of resting bioelectrical activity in children diagnosed with dyslexia.

Material and methods: Resting EEG activity was registered in 36 children with dyslexia and 27 gender- and age-matched control subjects during rest with eyes open or closed. EEG signal was analyzed using method of quantitative EEG (qEEG). Prior to the EEG data acquisition each subject performed tests for reading regular and artificial words.

Results: A specific pattern of resting EEG activity in children with dyslexia was identified. It was characterized by increased delta, theta and beta $(18-35 \mathrm{~Hz})$ rhythms power. Moreover, only in the control group the delta and theta power negatively correlated with the performance on the regular reading test at frontal, central and posterior electrodes. In children with dyslexia resting state beta $(18-35 \mathrm{~Hz})$ power at T5 and T6 scalp sites was related to phonological encoding (artificial words reading). 
Conclusions: The results of the study on the bioelectrical resting EEG activity in children diagnosed with dyslexia indicate a significant association of delta, theta and beta $(18-35 \mathrm{~Hz})$ rhythms with the reading process. This study may have important implications for diagnosis and therapy of children with language disorders.

Key words: dyslexia • resting EEG activity • quantitative EEG (qEEG)

\section{Wstęp}

Dysleksja to specyficzne trudności w czytaniu, za które nie są odpowiedzialne: wiek umysłowy dziecka, deficyty sensoryczne lub nieadekwatny proces nauczania [1]. Zaburzenie te może dotyczyć zdolności rozumienia czytanego tekstu, rozpoznawania czytanych słów, umiejętności głośnego czytania. Często towarzyszą mu również trudności w opanowaniu poprawnej pisowni. Dysleksję charakteryzują zaburzenia dekodowania pojedynczych wyrazów sensownych i pseudowyrazów, a także deficyt świadomości fonologicznej, która jest najczęściej definiowana jako „świadomy dostęp do fonemowego poziomu dźwięków mowy oraz umiejętności poznawczego manipulowania reprezentacjami na tym poziomie" [2, s. 362].

Badania nad etiologią dysleksji prowadzone są od kilkudziesięciu lat, a dotyczą one m.in. struktury mózgu, funkcjonowania systemu odpornościowego i gospodarki hormonalnej oraz ich wpływu na ośrodkowy układ nerwowy (OUN). U różnych dzieci dysleksję mogą powodować odmienne czynniki, a u tego samego dziecka może wystąpić kilka przyczyn jednocześnie. Wiele danych wskazuje, że specyficzne trudności w czytaniu i pisaniu mają podłoże genetyczne [3,4]. Przyczyn dysleksji upatruje się również w opóźnionym dojrzewaniu OUN [5], mikrouszkodzeniach okolic mózgu, które realizują umiejętności czytania i pisania [patrz: praca poglądowa 6], czy też nadprodukcji testosteronu w okresie prenatalnym, powodującej zablokowanie rozwoju lewej półkuli mózgu i kompensacyjny rozwój półkuli prawej [7].

Liczne badania genetyczne oraz wykorzystujące nowoczesne metody neuroobrazowania wskazują na trudności w sformułowaniu jednej, spójnej teorii wyjaśniającej przyczyny występowania dysleksji. Koncepcji jest wiele, ale nie wykluczają się one wzajemnie, a każda z nich przybliża do sformułowania decydującej odpowiedzi na pytanie o patomechanizm specyficznych trudności w czytaniu i pisaniu. Jedna z najbardziej rozpowszechnionych teorii zakłada, że dysleksja spowodowana jest deficytem fonologicznym, który przejawia się trudnością w zakresie różnicowania dźwięków mowy, manipulacji cząstkami fonologicznymi (sylabami, głoskami) oraz kodowania dźwięków mowy (fonemów) na znaki graficzne (grafemy) [8]. Inna teoria zakłada uszkodzenie wzrokowego systemu wielkokomórkowego, które przejawia się zaburzoną umiejętnością wychwytywania szybkich zmian w informacji docierającej do mózgu [9]. Dysleksję wyjaśnia się także w kategoriach zaburzeń funkcji móżdżku, który jest zaangażowany w procesy uczenia się zautomatyzowanych czynności (takich jak czytanie, pisanie) [10] oraz deficytów uwagi [11] i wzrokowej pamięci operacyjnej [12]. Jedna ze współczesnych koncepcji tłumaczących trudności dyslektyczne zakłada współistnienie dwóch niezależnych od siebie źródeł trudności w nabywaniu umiejętności czytania i pisania: deficytu przetwarzania fonologicznego i deficytu szybkiego nazywania [13].
Choć przyczyny dysleksji nie zostały do końca poznane, wiadomo, że specyficzne trudności w czytaniu i pisaniu współwystępują ze zmianami strukturalnymi i czynnościowymi w mózgu. Jednym z obiecujących kierunków poszukiwań mózgowych mechanizmów dysleksji jest badanie spoczynkowej aktywności mózgu metodą czynnościowego rezonansu magnetycznego (ang. resting state $f M R I$, rs-fMRI) oraz ilościowej elektroencefalografii (ang. quantitative EEG, $\mathrm{qEEG).}$

Termin,,aktywność spoczynkowa mózgu” odnosi się do czynności mózgu podczas braku zewnętrznej stymulacji [14]. Przykładowo, metodą fMRI można zbadać połączenia czynnościowe (ang. functional connectivity) między różnymi strukturami mózgu, które współdziałają, podczas gdy osoba badana leży wewnątrz skanera rezonansu i nie wykonuje żadnego zadania. Te połączone, współpracujące ze sobą, obszary mózgu tworzą tzw. „sieci spoczynkowe". Na szczególną uwagę zasługuje tzw. sieć defaultowa (ang. Default Mode Network, DMN), która jako jedyna ulega supresji podczas angażowania zasobów poznawczych w przetwarzanie bodźców zewnętrznych. Tworzą ją następujące regiony mózgu: przyśrodkowa część płata skroniowego, przyśrodkowa część kory przedczołowej, tylna część zakrętu obręczy/przedklinek, przyśrodkowa i podstawna część płata ciemieniowego. Funkcja sieci defaultowej jest obecnie przedmiotem intensywnych badań. Naukowcy podejrzewają, że DMN jest zaangażowana w generowanie myśli odnoszących się do siebie oraz do stanów mentalnych innych osób, a także, że odzwierciedla fizjologiczne procesy mózgowe.

Dotychczas udowodniono istnienie zmian w aktywności mózgowych sieci spoczynkowych w różnych zaburzeniach neurologicznych i psychiatrycznych, włączając deficyty neurorozwojowe [15-18]. W dysleksji podczas badania stanu spoczynkowego wykazano obniżoną, w porównaniu z osobami bez zaburzeń czytania, koherencję struktur mózgu aktywnych podczas czytania (styk skroniowo-ciemieniowy, obszary czołowe oraz skroniowe lewej półkuli) [19]. Autorzy tej pracy podejrzewają, że zmiany w zakresie koordynacji pobudzeń neuronów w regionach zaangażowanych w procesy czytania mogą stanowić podłoże deficytów poznawczych obserwowanych u osób z dysleksją. W niedawno opublikowanej pracy tego zespołu przedstawiono wyniki badań metodą rs-fMRI wykonanych u dzieci ze specyficznymi zaburzeniami czytania w celu oceny zmian neuroplastycznych mózgu po terapii [20]. Okazało się, że u osób, u których obserwowano największą poprawę, stwierdzono silniejsze niż u uczestników badania, którzy nie odnieśli większych korzyści z terapii bądź nie mieli dysleksji, połączenia funkcjonalne między lewą bruzdą wewnątrzciemieniową a lewym zakrętem wrzecionowatym i prawym środkowym zakrętem potylicznym. Autorzy wskazują na użyteczność badania spoczynkowej aktywności mózgu w ocenie efektywności oddziaływań terapeutycznych u dzieci z zaburzeniami czytania i pisania. 
W badaniach elektrofizjologicznych, za pomocą elektrod rozmieszczonych na powierzchni głowy, rejestruje się zmiany napięcia wywołane głównie przez synchroniczną, zbiorczą aktywność komórek nerwowych kory mózgu [21]. Typowo podczas badania zbiera się sygnał EEG w sytuacji, gdy osoba badana jest proszona o zrelaksowanie się z oczami otwartymi lub zamkniętymi. Analiza ilościowa EEG polega na zastosowaniu przekształceń matematycznych w celu wyodrębnienia $z$ sygnału bioelektrycznego poszczególnych składowych częstotliwości. Tradycyjnie wyróżnia się następujące zakresy fal mózgu: delta $(1-4 \mathrm{~Hz})$, theta $(4-8 \mathrm{~Hz})$, alfa $(8-13 \mathrm{~Hz})$ oraz beta $(13-30 \mathrm{~Hz})$ [22].

W zaburzeniach neurorozwojowych, takich jak ADHD czy dysleksja, stwierdza się odmienne wzorce pobudliwości sieci neuronalnych, które mogą stanowić swoiste markery tych deficytów. Niewiele jest badań z zastosowaniem ilościowej analizy sygnału EEG u dzieci z dysleksją, a ich wyniki są niejednoznaczne. Babiloni i współpracownicy [23] obserwowali zmiany w zakresie rytmu alfa w okolicach skroniowych, ciemieniowych i potylicznych, które istotnie korelowały z szybkością czytania pseudowyrazów. Im większa moc sygnału alfa, tym krótszy czas czytania. Inni autorzy [24,25] wykazali zmiany w zakresie rytmu theta i beta u dzieci z dysleksją. Istnieją również doniesienia o braku specyficznego wzorca bioelektrycznej aktywności spoczynkowej u osób z dysleksją [26-28]. Rozbieżności rezultatów powyższych badań skłoniły nas do sprawdzenia, czy stosując analizę ilościową sygnału EEG możemy zidentyfikować aktywność spoczynkową kory mózgu charakterystyczną dla dzieci z dysleksją.

\section{Materiał i metoda}

W badaniu uczestniczyło 36 dzieci (18 dziewczynek i 18 chłopców, średni wiek: 12 lat i 4 miesiące $\pm 1,5$ roku) z rozpoznaną dysleksją oraz 27 dzieci (16 dziewczynek, 11 chłopców, średni wiek: 13 lat \pm 2 lata) z prawidłowym słuchem (standardowa audiometria tonalna). Wszystkie osoby badane były praworęczne [29] i w normie intelektualnej [30]. Pozostałe informacje na temat dzieci uczestniczących $\mathrm{w}$ badaniu pochodziły $\mathrm{z}$ wywiadów przeprowadzonych z ich opiekunami. Diagnostyka dysleksji została przeprowadzona przez psychologów i pedagogów zatrudnionych $\mathrm{w}$ poradniach psychologiczno-pedagogicznych $\mathrm{w}$ Warszawie $\mathrm{z}$ zastosowaniem standaryzowanej baterii testów. U dzieci z rozpoznanymi specyficznymi zaburzeniami czytania nie stwierdzono żadnych współwystępujących zaburzeń neurorozwojowych (ADHD, ADD, autyzm, opóźniony rozwój mowy). Żaden uczestnik badania nie miał urazów głowy, zaburzeń neuropsychiatrycznych ani nie przyjmował leków mogących wpływać na OUN.

Opiekun każdego dziecka wyraził pisemną świadomą zgodę na jego uczestnictwo w badaniach. Zastosowane procedury uzyskały zgodę Komisji Bioetycznej przy Instytucie Fizjologii i Patologii Słuchu.

Przed badaniem elektrofizjologicznym wszystkie dzieci wykonały test czytania wyrazów sensownych (wersja eksperymentalna) oraz standaryzowany test czytania pseudowyrazów („Łatysz”, [31]). W obu ww. testach zadanie polegało na głośnym przeczytaniu jak największej liczby wyrazów w ciągu 1 minuty. Test czytania sensownych wyrazów zawiera 130 dwu- i trzysylabowych wyrazów rozmieszczonych w 5 kolumnach. „Łatysz” składa się z 71 jedno-, dwu-, trzy- lub czterosylabowych, nieistniejących w języku polskim, sztucznych wyrazów wydrukowanych na 1 karcie w 13 wersach. Analizowano liczbę poprawnie przeczytanych słów w zadanym czasie.

Spoczynkową aktywność bioelektryczną mózgu rejestrowano podczas standardowej procedury relaksacji w dwóch 3-minutowych blokach: 1) z oczami otwartymi i 2) z oczami zamkniętymi. Kolejność bloków „oczy otwarte” i „oczy zamknięte" była losowa.

Sygnał EEG rejestrowano za pomocą 21-kanałowego aparatu firmy Mitsar. Dziewiętnaście elektrod rozmieszczono zgodnie z międzynarodowym systemem 10-20 [32]. Oporność wszystkich elektrod wynosiła mniej niż $5 \mathrm{k} \Omega$. Sygnał EEG rejestrowano względem sprzężonych płatków uszu i filtrowano w paśmie od $0,5 \mathrm{~Hz}$ do $50 \mathrm{~Hz}$. Częstotliwość próbkowania wynosiła $250 \mathrm{~Hz}$.

Sygnał EEG poddano analizie ilościowej (qEEG), używając oprogramowania Win EEG (Mitsar). Artefakty z ruchów gałek ocznych usunięto, stosując metodę Independent Component Analysis (ICA), poprzez eliminację składowych korespondujących z mruganiem oczu $[33,34]$. Segmenty sygnału EEG $\mathrm{z}$ amplitudą $>100 \mu \mathrm{V}$ i/lub $\mathrm{z}$ amplitudą $>35 \mu \mathrm{V}$ w paśmie $20-35 \mathrm{~Hz}$ oraz $>50 \mu \mathrm{V}$ w paśmie $0-1 \mathrm{~Hz}$ ) zostały automatycznie oznaczone i wyłączone $\mathrm{z}$ dalszej analizy.

Następnie sygnał EEG podzielono na 4,096-sek. segmenty i poddano analizie widmowej metodą transformaty Fouriera (ang. Fast Fourier Transform, FFT). Obliczono bezwzględne widma mocy oddzielnie dla każdego bloku („oczy otwarte” i „oczy zamknięte”) u każdej osoby badanej. Widma mocy powstałe $\mathrm{z}$ uśrednień sygnału $\mathrm{z}$ mniej niż 30 segmentów nie zostały włączone do dalszych analiz.

Przedmiotem analizy były widma mocy bezwzględnej następujących zakresów częstotliwości: delta $(1,5-4 \mathrm{~Hz})$, theta $(4-8 \mathrm{~Hz})$, alfa $(8-12 \mathrm{~Hz})$, nisko- $(12-15 \mathrm{~Hz})$, średnio(15-18 Hz) i wysokoczęstotliwościowa $(18-35 \mathrm{~Hz})$ beta.

Wykonano statystyczną analizę porównawczą mocy sygnału EEG u dzieci z dysleksją i ich rówieśników bez zaburzeń czytania oddzielnie dla każdego z wyróżnionych pasm częstotliwości. W tym celu zastosowano analizę wariancji z powtarzanym pomiarem, w której uwzględniono następujące czynniki: „Blok” („oczy otwarte” vs „oczy zamknięte”) i „Elektroda” (n=19) jako powtarzane pomiary oraz "Grupa” („dysleksja” vs „grupa kontrolna”) jako czynnik międzyobiektowy. Ponadto policzono korelacje Pearsona między wynikami testów czytania a bezwzględną mocą sygnału dla poszczególnych zakresów częstotliwości obliczonych indywidualnie dla każdej osoby badanej i dla każdej z elektrod oddzielnie dla bloków: „oczu otwartych” i „oczu zamkniętych”. Analizy korelacyjne wykonano osobno u dzieci z dysleksją i w grupie kontrolnej.

\section{Wyniki}

Zgodnie z oczekiwaniami dzieci z dysleksją przeczytały istotnie $(\mathrm{t}(1,35)=6,34, \mathrm{p}<0,001)$ mniej wyrazów sensownych 

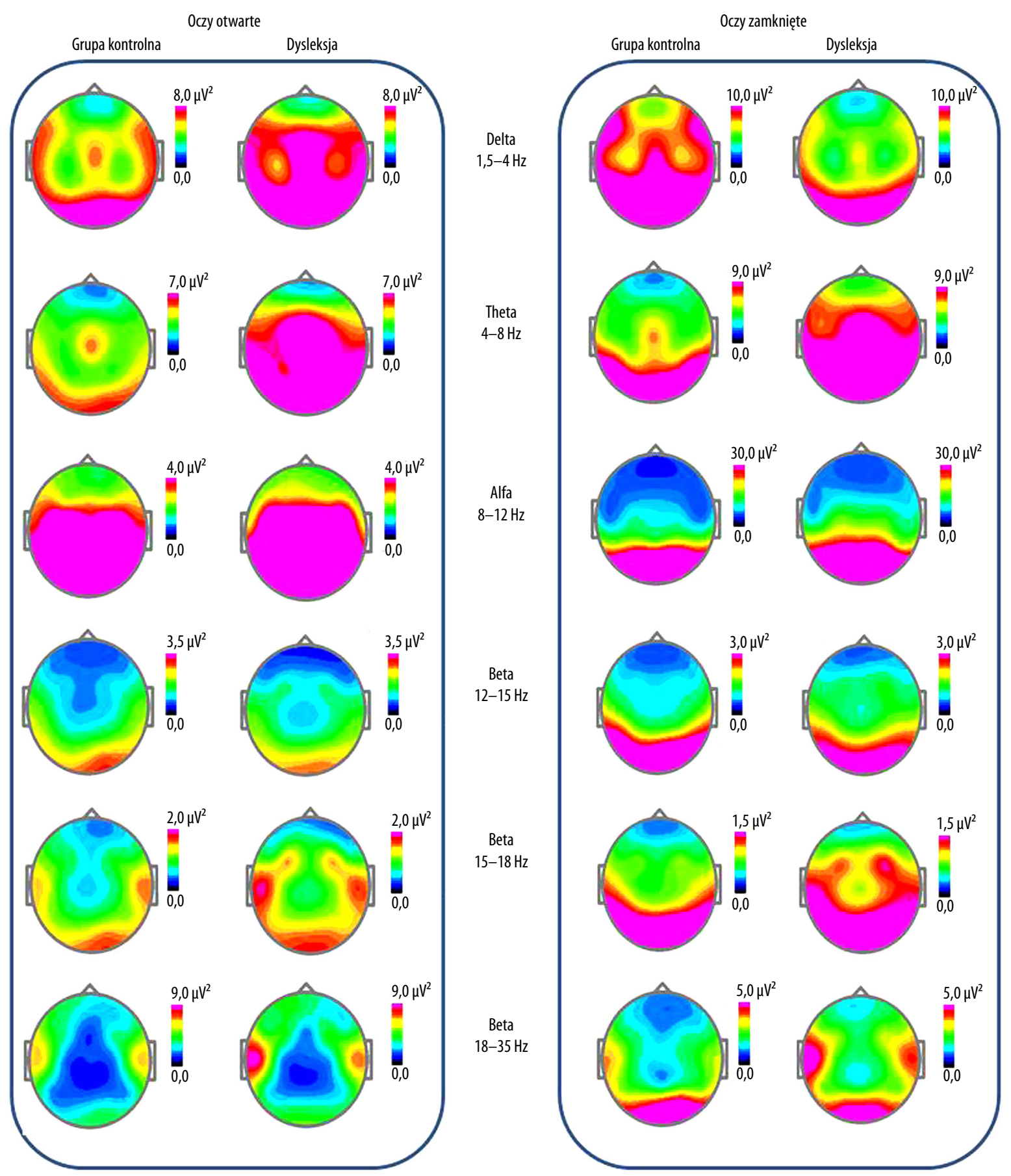

Rycina 1. Porównanie map rozkładów mocy bezwzględnej w różnych pasmach częstotliwości obliczane z sygnałów EEG zarejestrowanych w dwóch stanach spoczynkowych (oczy otwarte i oczy zamknięte) u dzieci z dyslekcją i w grupie kontrolnej

Figure 1. Comparison of the absolute spectra power distribution for different frequency bands calculated from EEG signal recorded in two resting states (eyes open and eyes closed) in children diagnosed with dyslexia and in control group

$(\mathrm{M}=39,3 ; \mathrm{SD}=23)$ i istotnie $(\mathrm{t}(1,35)=9,01 ; \mathrm{p}<0,001)$ mniej pseudowyrazów $(M=22,3, S D=11)$ w porównaniu $\mathrm{z}$ grupą kontrolną ( $M=71, S D=14$ i $M=51, S D=14$, odpowiednio dla wyrazów sensownych i „Łatysza”).

Wyniki analizy ilościowej sygnału EEG przedstawiono na rycinie 1.

\section{Rytm delta}

Stwierdzono istotny efekt główny „Grupy” $(\mathrm{F}(1,61)=9,17$; $\mathrm{p}<0,01)$ oraz „Bloku” $(\mathrm{F}(1,61)=8,40 ; \mathrm{p}<0,01)$. Dzieci $\mathrm{z}$ dysleksją uzyskały wyższą moc sygnału w paśmie delty $\left(\mathrm{M}=8,9 \mu \mathrm{V}^{2}, \mathrm{SE}=0,62 \mu \mathrm{V}^{2}\right)$ niż grupa kontrolna $\left(\mathrm{M}=6,1 \mu \mathrm{V}^{2}, \mathrm{SE}=0,71 \mu \mathrm{V}^{2}\right)$. Efekt interakcji „Grupa” $\times$ „Elektroda” $(\mathrm{F}(1,61)=2,77 ; \mathrm{p}<0,05)$ wskazuje, że różnice 
Tabela 1. Współczynniki korelacji Pearsona między wynikami testów czytania a bezwzględną mocą sygnału EEG w paśmie delta $(1,5-4 \mathrm{~Hz})$ na poszczególnych elektrodach. Korelacje istotne statystycznie $(p<0,05)$ zapisano pogrubioną czcionką

Table 1. The Pearson's correlation coefficients between the results of reading tests and absolute EEG delta (1.5-4 Hz) power on the electrodes applied. Significant correlations $(p<0.05)$ are bolded

\begin{tabular}{|c|c|c|c|c|c|c|c|c|c|c|c|c|c|c|c|c|c|c|c|}
\hline \multicolumn{20}{|c|}{ Rytm delta („oczy otwarte”) } \\
\hline Elektroda & Fp1 & Fp2 & F7 & F3 & $\mathrm{Fz}$ & F4 & F8 & T3 & C3 & $\mathrm{Cz}$ & C4 & T4 & T5 & P3 & $\mathbf{P z}$ & P4 & T6 & 01 & 02 \\
\hline \multicolumn{20}{|c|}{ Czytanie wyrazów sensownych } \\
\hline Dysleksja & -.21 & -.06 & -.23 & -.23 & -.08 & -.05 & -.18 & -.04 & .04 & -.06 & -.09 & -.19 & .04 & -.07 & .12 & .06 & -.01 & .07 & .02 \\
\hline Grupa kontrolna & -.28 & -.30 & -.07 & -.44 & -.45 & -.41 & -.05 & -.31 & -.63 & -.51 & -.42 & -.30 & -.48 & -.41 & -.37 & -.40 & -.44 & -.41 & -.50 \\
\hline \multicolumn{20}{|c|}{ Czytanie pseudowyrazów } \\
\hline Dysleksja & .01 & .08 & -.16 & -.12 & .11 & .03 & .08 & -.02 & .09 & .04 & -.09 & -.15 & .09 & .0 & .08 & .10 & .09 & .20 & .13 \\
\hline Grupa kontrolna & -.27 & -.15 & -.09 & -.20 & -.11 & -.10 & .03 & -.03 & -.29 & -.22 & -.09 & -.07 & -.11 & -.07 & -.12 & -.17 & -.11 & -.12 & -.11 \\
\hline
\end{tabular}

Tabela 2. Współczynniki korelacji Pearsona między wynikami testów czytania a bezwzględną mocą sygnału EEG w paśmie theta $(4-8 \mathrm{~Hz})$ na poszczególnych elektrodach. Korelacje istotne statystycznie $(p<0,05)$ zapisano pogrubioną czcionką

Table 2. The Pearson's correlation coefficients between the results of reading tests and absolute EEG theta (4-8 Hz) power on the electrodes applied. Significant correlations $(p<0.05)$ are bolded

\begin{tabular}{|c|c|c|c|c|c|c|c|c|c|c|c|c|c|c|c|c|c|c|c|}
\hline \multicolumn{20}{|c|}{ Rytm theta („oczy otwarte”) } \\
\hline Elektroda & Fp1 & $\mathrm{Fp} 2$ & F7 & F3 & Fz & F4 & F8 & T3 & C3 & Cz & C4 & T4 & T5 & P3 & $\mathbf{P z}$ & P4 & T6 & 01 & 02 \\
\hline \multicolumn{20}{|c|}{ Czytanie wyrazów sensownych } \\
\hline Dysleksja & -.18 & -.11 & -.12 & -.20 & -.24 & -.19 & -.12 & -.17 & -.05 & -.13 & -.10 & -.13 & -.05 & -.12 & .02 & .01 & -.07 & -.02 & -.02 \\
\hline Grupa kontrolna & -.28 & -.35 & -.08 & -.47 & -.39 & -.45 & .02 & -.35 & -.53 & -.48 & -.51 & -.34 & -.42 & -.42 & -.44 & -.45 & -.39 & -.35 & -.46 \\
\hline \multicolumn{20}{|c|}{ Czytanie pseudowyrazów } \\
\hline Dysleksja & -.13 & -.07 & -.13 & -.21 & -.18 & -.17 & -.07 & -.21 & -.02 & -.07 & -.11 & -.16 & -.05 & -.12 & -.03 & -.02 & -.07 & .05 & -.01 \\
\hline Grupa kontrolna & -.27 & -.16 & -.09 & -.24 & -.21 & -.08 & .08 & -.13 & -.22 & -.19 & -.20 & -.09 & -.24 & -.06 & -.07 & -.16 & -.09 & -.03 & -.09 \\
\hline
\end{tabular}

międzygrupowe w zakresie mocy fali delta nie pojawily się tylko na elektrodach Fp1 i Fp2. Moc sygnału dla pasma delty przy „oczach otwartych” była mniejsza niż przy „oczach zamkniętych” (odpowiednio: $M=6,82, \mathrm{SE}=0,33$ i $\mathrm{M}=8,17, \mathrm{SE}=0,67)$. Pozostałe efekty były nieistotne statystycznie.

\section{Rytm theta}

Wykazano istotnie $(\mathrm{F}(1,61)=4,12 ; \mathrm{p}<0,05)$ wyższą moc sygnału w zakresie częstotliwości theta $\mathrm{u}$ dzieci dyslektycznych $\left(\mathrm{M}=8,72 \mu \mathrm{V}^{2}, \mathrm{SE}=1,07 \mu \mathrm{V}^{2}\right)$ niż u dzieci z grupy kontrolnej $\left(\mathrm{M}=5,39 \mu \mathrm{V}^{2}, \mathrm{SE}=1,24 \mu \mathrm{V}^{2}\right)$. Tak jak w przypadku rytmu delta, istotnie $(\mathrm{F}(1,61)=22,70 ; \mathrm{p}<0,001)$ większą moc sygnału obserwowano dla „oczu zamkniętych” $\left(\mathrm{M}=8,70 \mu \mathrm{V}^{2}, \mathrm{SE}=1,14 \mu \mathrm{V}^{2}\right)$ niż dla „oczu otwartych” $\left(\mathrm{M}=5,40 \mu \mathrm{V}^{2}, \mathrm{SE}=054 \mu \mathrm{V}^{2}\right)$.

\section{Rytm alfa}

Dzieci z dysleksją i grupa kontrolna nie różniły się istotnie w zakresie mocy sygnału o częstotliwości alfa. Jedynie istotny statystycznie był efekt główny „Bloku” $(\mathrm{F}(1,61)=76,97$; $\mathrm{p}<0,001)$, który oznaczał wyższą moc sygnału rejestrowanego przy „oczach zamkniętych” niż „oczach otwartych” $\left(\mathrm{M}=17,07 \mu \mathrm{V}^{2}, \mathrm{SE}=1,5 \mu \mathrm{V}^{2}\right.$ vs $\left.\mathrm{M}=6,0 \mu \mathrm{V}^{2}, \mathrm{SE}=0,59 \mu \mathrm{V}^{2}\right)$.

\section{Rytm beta (12-18 Hz)}

Zarówno dla rytmu niskoczęstotliwościowego (12-15 Hz), jak i średnioczęstotliwościowego $(15-18 \mathrm{~Hz})$ nie stwierdzono istotnych statystycznie efektów głównych ani interakcji.

\section{Rytm beta $(18-35 \mathrm{~Hz})$}

Wykazano istotny efekt główny „Grupy” (F $(1,61)=15,41$; $\mathrm{p}<0,001)$, który przejawiał się wyższą mocą sygnału u dzieci $\mathrm{z}$ dysleksją $\left(\mathrm{M}=3,01 \mu \mathrm{V}^{2}, \mathrm{SE}=0,21 \mu \mathrm{V}^{2}\right)$ w porównaniu $\mathrm{z}$ grupą kontrolną $\left(\mathrm{M}=1,79 \mu \mathrm{V}^{2}, \mathrm{SE}=0,24 \mu \mathrm{V}^{2}\right)$ oraz efekt główny „Bloku” $(\mathrm{F}(1,61)=5,64 ; \mathrm{p}<0,05)$. Moc sygnału w sytuacji „oczu otwartych” była wyższa $\left(\mathrm{M}=2,63 \mu \mathrm{V}^{2}\right.$, $\left.\mathrm{SE}=0,20 \mu \mathrm{V}^{2}\right)$ niż dla „oczu zamkniętych” $\left(\mathrm{M}=2,18 \mu \mathrm{V}^{2}\right.$, $\mathrm{SE}=0,17 \mu \mathrm{V}^{2}$ ).

\section{Analiza korelacji}

Tylko w grupie kontrolnej wykazano istotne ujemne korelacje wyników testu czytania słów sensownych z bezwzględną mocą sygnału EEG w paśmie delta oraz theta, zarejestrowanego na większości elektrod dla warunku „oczu otwartych" (tabela 1 i 2). Im więcej poprawnie przeczytanych sensownych wyrazów, tym mniejsza moc sygnału w tych pasmach. 
Tylko u dzieci z dysleksją wyniki testu "Łatysz” istotnie korelowały z mocą sygnału EEG przy „oczach otwartych”, w zakresie wysokoczęstotliwościowego rytmu beta na elektrodach T5 $(r=0,34 ; \mathrm{p}<0,01)$ i T6 $(r=0,42 ; \mathrm{p}<0,05)$. Im więcej poprawnie przeczytanych pseudowyrazów, tym większa moc sygnału.

Korelacje mocy sygnału EEG w poszczególnych pasmach dla „oczu zamkniętych” nie były istotne statystycznie.

\section{Dyskusja}

W pracy przedstawiono wyniki badań bioelektrycznej aktywności spoczynkowej mózgu u dzieci z dysleksją. W grupie tej wykazano nadmierną ekspresję fal wolnych: delta i theta oraz wysokoczęstotliwościowej fali beta (rycina 1). Ponadto okazało się, że moc sygnału delta i theta była istotnie związana z procesem czytania sensownych słów, ale tylko u dzieci bez dysleksji: im więcej poprawnie przeczytanych wyrazów, tym mniejsza moc sygnału w paśmie fal wolnych (tabele 1 i 2). Z kolei, moc sygnału beta na elektrodach skroniowych dodatnio korelowała z szybkością czytania sztucznych wyrazów, tj. im więcej przeczytanych wyrazów, tym wyższa moc sygnału. Efekt ten zaobserwowano jedynie u dzieci z dysleksją.

Jak wspomniano we wstępnej części tej pracy, istniejące doniesienia dotyczące spoczynkowej aktywności bioelektrycznej mózgu w dysleksji przynoszą niejednoznaczne rezultaty. Uzyskane przez nas wyniki nie potwierdzają obserwacji Babiloniego i wsp. [23], którzy wykazali odmienny wzorzec spoczynkowej fali alfa u dzieci ze specyficznymi zaburzeniami czytania. Inni autorzy [24,35-37] wykazali nadmierną ekspresję fal delta i theta u dzieci z dysleksją podczas wykonywania różnych zadań angażujących umiejętności fonologiczne. W prezentowanych w naszej pracy badaniach związek fal wolnych z szybkością czytania został wykazany wyłącznie u dzieci bez dysleksji. Warto jednak zauważyć, że moc sygnału EEG w paśmie delta i theta istotnie korelowała tylko $\mathrm{z}$ liczbą poprawnie przeczytanych słów sensownych. Czytanie wyrazów istniejących w języku ojczystym dziecka, z którymi miało ono wcześniej styczność, nie jest procesem angażującym „czyste” umiejętności fonologiczne. Proces ten wymaga nie tylko różnicowania grafemów i fonemów, lecz także kojarzenia rozpoznawanych znaków z posiadanym doświadczeniem. Niewykluczone więc, że skorelowany z czytaniem rytm delta i theta $\mathrm{u}$ dzieci bez dysleksji odzwierciedla zaangażowanie funkcji poznawczych, takich jak uwaga i pamięć wyrazów, związanych z przetwarzaniem fonologicznym. Wniosek ten wydaje się bardziej prawdopodobny, jeśli weźmiemy pod uwagę fakt, że u dzieci z grupy kontrolnej nie wykazano istotnego związku między mocą sygnału w paśmie fal wolnych a poziomem wykonania testu czytania sztucznych wyrazów, który pozwala ocenić dekodowanie bez odwoływania się do znaczenia.

W badaniach przedstawionych w niniejszej pracy wykazano zwiększoną moc sygnału w paśmie delta i theta u dzieci z dysleksją w porównaniu $\mathrm{z}$ ich rówieśnikami bez zaburzeń czytania. Zwiększoną ekspresję czynności delta obserwuje się często u dzieci z zaburzeniami uwagi, np. z ADHD [38]. Dokładne funkcjonalne znaczenie i miejsce generacji w mózgu rytmu delta wciąż pozostaje niejasne i jest przedmiotem prowadzonych badań. Udowodniono, że sygnał EEG rejestrowany z uszkodzonych obszarów kory lub obszarów $\mathrm{z}$ nimi sąsiadujących zawiera więcej fal wolnych (głównie delta oraz theta) [39,40]. Jako potencjalne źródło generacji fal delta wymienia się przede wszystkim struktury podkorowe w tym wzgórze i struktury układu limbicznego [41]. Struktury te zaangażowane są w utrzymanie odpowiedniego poziomu wzbudzenia w korze mózgowej, od którego istotnie zależy poziom przetwarzania informacji w korze mózgu. Nadmiar fal delta może więc wskazywać na trudności w zakresie utrzymania wzbudzenia, a w konsekwencji na obniżoną gotowość do odbioru bodźców i dekodowania napływającej informacji.

Z kolei rytm theta ma związek z procesami pamięciowymi, zwłaszcza z pamięcią operacyjną [42]. Uważa się, że u dzieci z ADHD jest on markerem „korowego zwolnienia" [43]: theta, nasilona zwłaszcza w przednich regionach mózgu, może powodować problemy z koncentracją uwagi [44] i wskazuje na niedoaktywowanie okolic czołowych [45] oraz nieprawidłowości w funkcjonowaniu związanych z nimi systemów uwagowych, odpowiedzialnych za funkcje wykonawcze czy pamięć operacyjną [46]. Według niektórych autorów nadmierna ekspresja thety w przednich obszarach mózgu może wskazywać na opóźnione dojrzewanie tych struktur [44].

Podsumowując, nadmierna ekspresja fali theta i delta $\mathrm{u}$ dzieci $\mathrm{z}$ dysleksją może być powiązana $\mathrm{z}$ deficytami uwagowymi i pamięciowymi, które często stwierdza się w dysleksji [47], a które nie pozostają bez wpływu na proces czytania.

Ponadto w prezentowanych w tej pracy badaniach u dzieci z dysleksją wykazano większą moc sygnału EEG w paśmie beta $(18-35 \mathrm{~Hz})$. Choć istotne statystycznie różnice międzygrupowe stwierdzono dla wszystkich elektrod łącznie, to na podstawie inspekcji widma fali beta (por. rycina 1) można stwierdzić, że zarówno podczas rejestracji sygnału EEG przy oczach otwartych, jak i zamkniętych, ekspresja fali beta u dzieci dyslektycznych jest szczególnie zawyżona w okolicach skroniowych (głównie lewej). Ponadto moc sygnału w paśmie wysokoczęstotliwościowej bety na elektrodach skroniowych (T5 i T6) korelowała dodatnio z liczbą poprawnie przeczytanych sztucznych słów w teście „Łatysz”. Wyniki te świadczą o związku fal szybkich z umiejętnościami fonologicznymi, które realizowane są właśnie w okolicach skroniowych mózgu. Choć w literaturze przedmiotu niewiele jest doniesień dotyczących roli czynności beta w procesie czytania czy przetwarzania fonologicznego, w niedawno opublikowanej pracy Penolazzi i wsp. [48] wykazano największy wzrost mocy sygnału EEG w paśmie 13-20 Hz w tylnych regionach mózgu u dzieci z dysleksją, u których tempo czytania uległo znacznemu usprawnieniu po zastosowanej terapii. Poszukiwanie związków fal szybkich z procesami językowymi wydaje się zatem obiecującym kierunkiem dalszych badań.

W pracy przedstawiono wyniki badań aktywności spoczynkowej mózgu oddzielnie dla dwóch warunków: relaksacji z oczami otwartymi lub zamkniętymi. Jest to typowa procedura rejestracji sygnału EEG, ponieważ od dawna wiadomo, że w oba te stany zaangażowane są odmienne procesy mózgowe. Wzrost czynności wolnej, zwłaszcza 
aktywności w zakresie alfa podczas zamknięcia oczu oraz jej spadek przy otwieraniu oczu, jest zjawiskiem znanym i wielokrotnie opisywanym w pracach [49]. Efekt ten, określany jako „reakcja zatrzymania”, jest przejawem prawidłowej reaktywności mózgu [50]. Dokładny mechanizm „reakcji zatrzymania” wciąż nie jest jasny [51]. Niektóre ze stawianych hipotez mówią, że desynchronizacja rytmu alfa, jaką obserwuje się po otwarciu oczu, odzwierciedla wzrost aktywności systemu wzrokowego spowodowany gwałtownym napływem informacji do analizatora wzrokowego. Inne teorie zakładają, że wzrost aktywności alfa jest przejawem zwiększenia synchronizacji w pętlach wzgórzowo-korowych, łączących jądra wzgórza z różnymi obszarami kory mózgu. Natomiast zmniejszenie aktywności związane byłoby z desynchronizacją pętli wzgórzowo-korowych, której celem byłoby ułatwienie przetwarzania informacji w polach wzrokowych. Efekt zwiększenia ekspresji fal po zamknięciu oczu nie ogranicza się jednak wyłącznie do czynności alfa. Barry i wsp. [52] udowodnili, że u młodych osób dorosłych w ogólnie dobrym stanie zdrowia po zamknięciu oczu dochodzi również do wzrostu czynności delta, theta a nawet beta. Mechanizm neuronalny i funkcja tych zjawisk może polegać na ułatwieniu przetwarzania lub generowania aktywności spoczynkowej w obszarach korowych związanych z modalnością inną niż wzrokowa. Obserwowany w naszych badaniach, zarówno u dzieci z dysleksją jak i u dzieci z grupy kontrolnej, efekt zwiększonej ekspresji fal wolnych po zamknięciu oczu wydaje się być zatem zjawiskiem prawidłowym.

\section{Wnioski}

Uzyskane wyniki wskazują na odrębny wzorzec bioelektrycznej aktywności spoczynkowej mózgu u dzieci z dysleksją. Nadmierna ekspresja fal szybkich $(18-35 \mathrm{~Hz})$, rejestrowanych zwłaszcza w okolicach skroniowych, może być związana z procesem czytania. Uogólniony efekt większej mocy sygnału EEG w paśmie fal wolnych (delta i theta) prawdopodobnie odzwierciedla inne niż zaburzenia językowe deficyty poznawcze (uwagi i pamięci operacyjnej). Analiza ilościowa sygnału EEG może być stosowana do poszerzenia diagnostyki oraz planowania i monitorowania postępów w terapii zaburzeń językowych.

\section{Podziękowania}

Badania finansowane z grantu Ministerstwa Nauki i Szkolnictwa Wyższego nr NN403214939.

\section{Piśmiennictwo:}

1. ICD-10: Klasyfikacja zaburzeń psychicznych i zaburzeń zachowania w ICD-10. Opisy kliniczne i wskazówki diagnostyczne. Warszawa: Vesalius \& IPN; 2000.

2. Stanovich KE. Matthew effects in reading: Some consequences of individual differences in the acquisition of literacy. Reading Research Quarterly, 1986; 21: 360-407.

3. Giraud AL, Ramus F. Neurogenetics and auditory processing in developmental dyslexia. Curr Opin Neurobiol, 2013; 23(1): 37-42.

4. Hensler BS, Schatschneider C, Taylor J, Wagner RK. Behavioral Genetic Approach to the Study of Dyslexia. J Dev Behav Pediatr, 2010; 31(7): 525-32.

5. Critchley M. The problem of developmental dyslexia. Proc R Soc Med, 1963; 56: 209-12.

6. Caylak E. Neurobiological Approaches on Brains of Children with Dyslexia. Acad Radiol, 2009; 16(8): 1003-24.

7. Behan P, Geschwind N. Dyslexia, Congenital Anomalies, and Immune Disorders: The Role of the Fetal Environmenta. Ann NY Acad Sci, 1985; 457(1): 13-18.

8. Liberman IY. Phonology and beginning reading revisited. Brain Read, 1989; 207-20.

9. Stein J, Walsh V. To see but not to read; the magnocellular theory of dyslexia. Trends Neurosci, 1997; 20(4): 147-52.

10. Nicolson RI, Fawcett AJ, Dean P. Developmental dyslexia: the cerebellar deficit hypothesis. Trends Neurosci, 24(9); 508-11.

11. Facoetti A, Turatto M, Lorusso ML, Mascetti GG. Orienting of visual attention in dyslexia: evidence for asymmetric hemispheric control of attention. Exp Brain Res, 2001; 138(1): 46-53.

12. Bosse ML, Tainturier MJ, Valdois S. Developmental dyslexia: The visual attention span deficit hypothesis. Cognition, 2007; 104(2): 198-230.

13. Wolf M, Bowers PG. Naming-speed processes and developmental reading disabilities: an introduction to the special issue on the double-deficit hypothesis. J Learn Disabil, 2000; 33(4): 322-24.
14. Fox MD, Raichle ME. Spontaneous fluctuations in brain activity observed with functional magnetic resonance imaging. Nat Rev Neurosci, 2007; 8(9): 700-11.

15. Snyder AZ, Raichle ME. A brief history of the resting state: The Washington University perspective. NeuroImage, 2012; 62(2): 902-10.

16. Greicius MD, Srivastava G, Reiss AL, Menon V. Default-mode network activity distinguishes Alzheimer's disease from healthy aging: evidence from functional MRI. Proc Natl Acad Sci USA, 2004; 101(13): 4637-42.

17. Greicius MD, Flores BH, Menon V, Glover GH, Solvason HB, Kenna $\mathrm{H}$ i wsp. Resting-state functional connectivity in major depression: abnormally increased contributions from subgenual cingulate cortex and thalamus. Biol Psychiatry, 2007; 62(5): 429-37.

18. Di Martino A, Zuo XN, Kelly C, Grzadzinski R, Mennes M, Schvarcz A i wsp. Shared and Distinct Intrinsic Functional Network Centrality in Autism and Attention-Deficit/Hyperactivity Disorder. Biol Psychiatry, 2013; 74(8): 623-32.

19. Koyama MS, Kelly C, Shehzad Z, Penesetti D, Castellanos FX, Milham MP. Reading Networks at Rest. Cereb Cortex, 2010; 20(11): 2549-59.

20. Koyama MS, Di Martino A, Kelly C, Jutagir DR, Sunshine J, Schwartz SJ i wsp. Cortical Signatures of Dyslexia and Remediation: An Intrinsic Functional Connectivity Approach. PLoS One, 2013; 8(2): e55454.

21. Wróbel A. Zbiorcza aktywność elektryczna mózgu. Kosmos, 1997; 46(3): 317-26.

22. Niedermeyer E, Lopes da Silva FH. Electroencephalography: basic principles, clinical applications and related fields. Lippincott Williams \& Wilkins; 2005.

23. Babiloni C, Stella G, Buffo P, Vecchio F, Onorati P, Muratori $\mathrm{C}$ i wsp. Cortical sources of resting state EEG rhythms are abnormal in dyslexic children. Clin Neurophysiol, 2012; 123(12): 2384-91. 
24. Klimesch W, Doppelmayr M, Wimmer H, Schwaiger J, Röhm $\mathrm{D}$, Gruber $\mathrm{W}$ i wsp. Theta band power changes in normal and dyslexic children. Clin Neurophysiol, 2001; 112(7): 1174-85.

25. Klimesch W, Doppelmayr M, Wimmer H, Gruber W, Röhm D, Schwaiger J i wsp. Alpha and beta band power changes in normal and dyslexic children. Clin Neurophysiol, 2001; 112(7): 1186-95.

26. Fein G, Galin D, Yingling CD, Johnstone J, Davenport L, Herron J. EEG spectra in dyslexic and control boys during resting conditions. Electroencephalogr Clin Neurophysiol, 1986; 63(2): $87-97$.

27. Rumsey JM, Coppola R, Denckla MB, Hamburger SD, Kruesi MJ. EEG spectra in severely dyslexic men: rest and word and design recognition. Electroencephalogr Clin Neurophysiol, 1989; 73(1): 30-40.

28. Ortiz T, Exposito FJ, Miguel F, Martin-Loeches M, Rubia FJ. Brain mapping in dysphonemic dyslexia: in resting and phonemic discrimination conditions. Brain Lang, 1992; 42(3): 270-85.

29. Oldfield RC. The assessment and analysis of handedness: The Edinburgh Inventory. Neuropsychologia, 1971; 9: 97-113.

30. Jaworowska A, Szustrowa T. Test Matryc Ravena w Wersji Standard - forma klasyczna. Warszawa: Pracownia Testów Psychologicznych; 2000.

31. Bogdanowicz M. Łatysz. Warszawa: Pracownia Testów Psychologicznych; 2008.

32. Jasper HH. Report of the Committee on Methods of Clinical Examination in Electroencephalography. Electroenceph. Clin. Neurophysiol, 1958; 10: 370-71.

33. Jung TP, Makeig S, Westerfield M, Townsend J, Courchesne E, Sejnowski TJ. Removal of eye activity artifacts from visual event-related potentials in normal and clinical subjects. Clin Neurophysiol, 2000; 111(10): 1745-58.

34. Vigário RN. Extraction of ocular artefacts from EEG using independent component analysis. Electroencephalogr Clin Neurophysiol, 1997; 103(3): 395-404.

35. Penolazzi B, Spironelli C, Angrilli A. Delta EEG activity as a marker of dysfunctional linguistic processing in developmental dyslexia. Psychophysiology, 2008; 45(6): 1025-33.

36. Soltész F, Szücs D, Leong V, White S, Goswami U. Differential Entrainment of Neuroelectric Delta Oscillations in Developmental Dyslexia. PLoS One, 2013; 8(10): e76608.

37. Spironelli C, Penolazzi B, Angrilli A. Dysfunctional hemispheric asymmetry of theta and beta EEG activity during linguistic tasks in developmental dyslexia. Biol Psychol, 2008; 77(2): 123-31.
38. Barry RJ, Clarke AR, Johnstone SJ. A review of electrophysiology in attention-deficit/hyperactivity disorder: I. Qualitative and quantitative electroencephalography. Clin Neurophysiol, 2003; 114(2): 171-83.

39. Murri L, Gori S, Massetani R, Bonanni E, Marcella F, Milani S. Evaluation of acute ischemic stroke using quantitative EEG: a comparison with conventional EEG and CT scan. Neurophysiol Clin, 1998; 28(3): 249-57.

40. Fernández-Bouzas A, Harmony T, Fernández T, Ricardo-Garcell J, Casián G, Sánchez-Conde R. Cerebral blood flow and sources of abnormal EEG activity (VARETA) in neurocysticercosis. Clin Neurophysiol, 2001; 112(12): 2281-7.

41. Knyazev GG. EEG delta oscillations as a correlate of basic homeostatic and motivational processes. Neurosci Biobehav Rev, 2012; 36(1): 677-95.

42. Klimesch W, Doppelmayr M, Yonelinas A, Kroll NEA, Lazzara M, Röhm D i wsp. Theta synchronization during episodic retrieval: neural correlates of conscious awareness. Cogn Brain Res, 2001; 12(1): 33-38.

43. Loo SK, Makeig S. Clinical Utility of EEG in Attention-Deficit/Hyperactivity Disorder: A Research Update. Neurotherapeutics, 2012; 9(3): 569-87.

44. Mann CA, Lubar JF, Zimmerman AW, Miller CA, Muenchen RA. Quantitative analysis of EEG in boys with attention-deficit-hyperactivity disorder: controlled study with clinical implications. Pediatr Neurol, 1992; 8(1): 30-36.

45. Loo SK, Barkley RA. Clinical utility of EEG in attention deficit hyperactivity disorder. Appl Neuropsychol, 2005; 12(2): 64-76.

46. Pliszka SR, McCracken JT, Maas JW. Catecholamines in attention-deficit hyperactivity disorder: current perspectives. J Am Acad Child Adolesc Psychiatry, 1996; 35(3): 264-72.

47. Skottun BC, Skoyles JR. Attention, reading and dyslexia. Clin Exp Optom, 2006; 89(4): 241-45.

48. Penolazzi B, Spironelli C, Vio C, Angrilli A. Brain plasticity in developmental dyslexia after phonological treatment: A beta EEG band study. Behav Brain Res, 2010; 209(1): 179-82.

49. Jasper HH. Cortical excitatory state and variability in human brain rhythms. Science, 1936; 83(2150): 259-60.

50. Chapman RM, Armington JC, Bragdon HR. A quantitative survey of kappa and alpha EEG activity. Electroencephalogr Clin Neurophysiol, 1962; 14: 858-68.

51. Fisch B, Spehlmann R. Fisch and Spehlmann's EEG Primer. Basic Principles of Digital and Analog EEG. Elsevier; 1999.

52. Barry RJ, Clarke AR, Johnstone SJ, Magee CA, Rushby JA. EEG differences between eyes-closed and eyes-open resting conditions. Clin Neurophysiol, 2007; 118(12): 2765-73. 